\title{
Analisis Rendahnya Keaktifan Kunjungan Ibu Balita Ke Posyandu Tompo Kecamatan Taopa Kabupaten Parigi Moutong
}

\author{
Sitti Radhiah $^{* 1}$, Chantika Rizkia Ayunda ${ }^{1}$, Hermiyanti ${ }^{2}$ \\ ${ }^{1}$ Departement of Biostatistics, Family Planning and Population, Faculty of Public Health, \\ Tadulako University, Indonesia \\ ${ }^{2}$ Departement of Health Administration and Policy, Faculty of Public Health, Tadulako \\ University, Indonesia
}

\section{Author's Email Correspondence (*):radhiahkasim@gmail.com Phone : +62878667474240}

\begin{abstract}
ABSTRAK
Posyandu merupakan wadah kegiatan pengembangan kualitas sumberdaya manusia sejak dini dalam mewujudkan kesejahteraan keluarga dan masyarakat. Kurangnya keaktifan kunjungan ibu dipengaruhi oleh pengetahuan, sikap dan dukungan keluarga. Perilaku ibu Balita untuk datang memanfaatkan pelayanan kesehatan yang ada di Posyandu merupakan upaya untuk mencegah atau mendeteksi sedini mungkin hambatan pada pertumbuhan Balita. Tujuan penelitian ini adalah untuk mengetahui faktor-faktor yang berpengaruh terhadap keaktifan kunjungan ibu Balita ke Posyandu di Wilayah kerja Puskesmas Taopa Kecamatan Taopa Kabupaten Parigi Moutong. Jenis penelitian ini adalah Cross Sectional. Populasi dalam penelitian ini adalah semuaibu yang mempunyai balita usia antara 24-60 bulan dan tercatat sebagai penduduk di wilayah kerja Puskesmas Taopa Kecamatan Taopa Kabupaten Parigi Moutong. Teknik pengambilan sampel dalam penelitian ini adalah Simple random sampling dengan jumlah sampel 106 orang. Analisis Data menggunakan univariat dan bivariat denganUji Regresi Logistik Berganda. Hasil penelitian ada pengaruh antara sikap $(\rho=0,001)$ dan dukungan keluarga $(\rho=0,000)$ terhadap perilaku keaktifan kunjungan ibu Balita ke Posyandu sedangkan pengetahuan $(\rho=0,848)$ tidak ada pengaruh terhadap perilaku keaktifan kunjungan ibu Balita ke Posyandu. Saran yang dapat diberikan kepada petugas kesehatan adalah sebaiknya mengajak ibu Balita untuk membawa balita ke Posyandu dan selalu mensosialisasikan serta memberi penyuluhan tentang pentingnya Posyandu khususnya manfaat maupun tujuan Posyandu.
\end{abstract}

Kata kunci : Dukungan keluarga; Pengetahuan; Perilaku; Posyandu; Sikap

Published by:

Tadulako University

Address:

Jl.Soekarno Hatta KM 9. Kota Palu, Sulawesi Tengah, Indonesia.

Phone: +628114120202

Email: Preventif.fkmuntad@gmail.com
Article history :

Received : 05112020

Received in revised form : 05112020

Accepted : 05112020

Available online 30062021 


\begin{abstract}
Integrated Healthcare Center is a forum for developing the quality of human resources from an early age in realizing the welfare of families and society. Knowledge, attitudes and family support influence the lack of active visiting mothers. The behaviour of toddler mothers to take advantage of health services at Integrated Healthcare Center is an effort to prevent or detect as early as possible obstacles to the growth of toddlers. This research aims to determine factors that influence toddler mothers' activeness to Integrated Healthcare Center at the Working Area of the Taopa Public Health Center, Taopa Subdistrict, Parigi Moutong District. This research was cross-sectial. This research's population was all mothers of toddlers aged between 24-60 months and were registered as residents at the working area of the Taopa Public Health Center, Taopa Subdistrict, Parigi Moutong District. The sample was taken through simple random sampling with a sample size of 106 people. Data were analyzed through univariate and bivariate with Multiple Logistic Regression Test. The results show an influence between attitude $(\rho=0.001)$ and family support $(\rho=0.000)$ on toddler mothers' dynamic behaviour visits to Integrated healthcare Center. In contrast, knowledge $(\rho=0.848)$ did not influence toddler mothers' dynamic behaviour to Integrated Healthcare Center. The health workers are suggested to invite the mothers to bring their toddlers to Integrated Healthcare Center and socialize and educate the importance of Integrated Healthcare Center, especially the benefits and objectives
\end{abstract}

Keywords: Family Support, Knowledge, Behavior, Integrated Healthcare Center, Attitude

\title{
PENDAHULUAN
}

Posyandu merupakan salah satu bentuk Upaya Kesehatan Bersumber Daya Masyarakat (UKBM) yang dikelola dan diselenggarakan dari, oleh, untuk dan bersama masyarakat dalam penyelenggaraan pembangunan kesehatan guna memberdayakan masyarakat dan memperoleh pelayanan kesehatan dasar untuk mempercepat penurunan angka kematian ibu dan bayi (1).

WHO (World Health Organization) melaporkan balita kurang gizi mempunyai resiko meninggal lebih tinggi dibandingkan dengan balita yang cukup gizi. Angka kematian balita secara global masih mengkhawatirkan setiap tahunnya, 2,6 juta bayi di seluruh dunia tak mampu bertahan hidup selama lebih dari satu bulan, serta adanya Kejadian Luar Biasa (KLB) campak pada Balita dengan total kasus mencapai 28.182 kasus dengan 13 kematian hingga agustus 2018 (2).

Indonesia terdapat empat provinsi dengan persentase tertinggi balita yang mendapat imunisasi lengkap yaitu di Provinsi Sumatera Selatan (102,3\%), Lampung (101,5\%), Jambi $(101,4 \%)$, Nusa Tenggara Barat $(100,2)$ dan Sulawesi Tengah berada di urutanke 17 dengan $(87,8 \%)$. Sedangkan provinsi dengan capaian terendah yaitu Kalimantan Utara (66,2\%), Papua (68,6\%), dan Aceh (70,0\%). Kabupaten/kota yang mencapai 80\% imunisasi dasar 
lengkap pada bayi merupakan salah satu indicator pemerataan dan mutu pelayanan kesehatan, dengan target 95\% pada tahun 2019 (3)

Data Dinas Kesehatan Kota Palu, menjelaskan bahwa cakupan imunisasi dasar lengkap di Provinsi Sulawesi Tengah tahun 2018 mencapai 90,1\% dengan target tahunan sebesar 95\%, adanya peningkatan cakupan disbanding dengan tahun sebelumnya sebesar $88 \%$ (4).

Pencapaian target nasional 60\%, kabupaten dengan capaian tertinggi dalam Posyandu aktif pada tahun 2018 yaitu Kabupaten Poso (77,03\%) sedangkan kabupaten dengan capaian terendah yaitu Kabupaten Buol (26,99\%). Pada Kabupaten Parigi Moutong mempunyai persentasi sebesar $(34,88 \%)$ yang belum mencapai target nasional (4).

Belum tercapainya target Posyandu aktif disebabkan oleh beberapa permasalahan yang merupakan tantangan yang harus di benahi untuk meningkatkan kualitas Posyandu antara lain adalah masih kurangnya komitmen pemerintah dalam menjalankan kebijakan-kebijakan yang dapat mendukung kegiatan Posyandu, misalnya menjalankan kebijakan Pokjanal Posyandu aktif baik dari tingkat kabupaten/kota sampai Pokja Posyandu di desa, alokasi operasional Posyandu yang masih perlu ditingkatkan, sosialisasi maupun pelatihan bagi kader Posyandu. Drop out kader juga masih terjadi dibeberapa Posyandu, masih banyak kader yang belum memahami cara pengisian balok SKDN, masih banyak kader yang belum memahami tentang konsep D/S dan masih banyak bidan desa yang belum memahami bagaimana cara meningkatkan strata Posyandu sehingga dapat meningkatkan jumlah Posyandu aktif yaitu strata purnama dan mandiri (5).

Berdasarkan studi pendahuluan yang dilakukan di Puskesmas Taopa, diperoleh dari petugas Puskesmas bahwa hasil data yang didapatkan tentang keaktifan kunjungan Balita ke Posyandu yang paling rendah persentase keaktifan kunjungannya adalah Desa Tompo. Desa ini merupakan desa yang tingkat keaktifan kunjungan ibu Balita ke Posyandu sangat kurang satu tahun terakhir dengan jumlah 143 balita dengan presentasi (24,3\%) (6).

Wawancara yang dilakukan dengan petugas kesehatan dikatakan bahwa yang menyebabkan kurangnya keaktifan kunjungan ibu balita ke Posyandu yaitu kurangnya pengetahuan, sikap seperti keyakinan ibu balita apabila membawa anaknya ke Posyandu akan membuat anak semakin sakit dan kurangnya dukungan keluarga.

Berdasarkan uraian latar belakang diatas maka tujuan dari penelitian ini adalah untuk mengetahui faktor-faktor yang berpengaruh terhadap keaktifan kunjungan ibu balita ke Posyandu di wilayah kerja Puskesmas Taopa Kecamatan Taopa Kabupaten Parigi Moutong. 


\section{METODE}

Penelitian ini adalah penelitian kuantitatif dengan pendekatan survey analitik, dengan desain Cross Sectional. Penelitian ini dilakukan untuk mengetahui hubungan dari 2 variabel, yaitu variabel independen (pengetahuan, sikap, dan dukungan keluarga) dengan variable dependen (perilaku keaktifan kunjungan ibu Balita ke Posyandu). Penelitian dilakukan di Posyandu Tompo Kecamatan Taopa Kabupaten Parigi Moutong, dari bulan agustus s/d september 2020. Populasi penelitian sebanyak 143 orang dan setelah dihitung menggunakan rumus Slovin didapatkan sampel sebanyak 106 orang. Teknik pengambilan sampel secara randomsampling. Analisis data yang digunakan adalah analisis univariat dan bivariat, analisis bivariat menggunakan uji regresilogistik dengan $a<(0,05)$.

\section{HASIL}

Tabel I

Hasil Analisis Univariat Karakteristik Responden

\begin{tabular}{lcc}
\hline Kelompok Umur & n & Percent $\mathbf{( \% )}$ \\
\hline 17-25 Tahun & 31 & 29,2 \\
26-35 Tahun & 43 & 40,6 \\
36-45 Tahun & 32 & 30,2 \\
\hline Total & 106 & 100,0 \\
\hline Pendidikan Terakhir & $\mathbf{n}$ & Percent $\mathbf{\%})$ \\
\hline Tidak Sekolah/ tidak tamat & 17 & 16,0 \\
SD & 38 & 35,8 \\
SD sedejarat & 24 & 22,6 \\
SMP sederajat & 26 & 24,5 \\
SMA sederajat & 1 & 0,9 \\
\hline Sarjana Universitas & 106 & 100 \\
\hline Total & $\mathbf{n}$ & Percent $\mathbf{( \% )}$ \\
\hline Pekerjaan saat ini & 104 & 98,1 \\
\hline Ibu rumah tangga & 2 & 1,9 \\
Guru honorer & 106 & 100,0 \\
\hline Total & &
\end{tabular}

Sumber : Data Primer,2020

Berdasarkan tabel 1 menunjukkan bahwa sebagian besar responden berusia 26-35 tahun sebanyak 43 responden (40,6\%), dan distribusi terendah pada rentan usia 17-24 tahun sebanyak 31 responden (29,2\%). Sebagian besar responden berpendidikan SD/Sederajatsebanyak 38 responden $(35,8 \%)$, dan terendah yaitu pada pendidikan Sarjana/Universitas sebanyak 1 responden $(0,9 \%)$. Sebagian besar responden memiliki 
pekerjaan sebagai ibu rumah tangga yaitu sebanyak 104 responden $(98,1 \%)$ dan distribusi terendah, pada pekerjaan sebagai guru honorer yaitu sebanyak 2 responden $(1,9 \%)$.

Tabel 2

Hasil Analisis Univariat Variabel Bebas Dan Terikat

\begin{tabular}{lcc}
\hline Pengetahuan & Frequency & Percent $(\%)$ \\
\hline Baik & 101 & 95,3 \\
Kurang Baik & 5 & 4,7 \\
\hline Total & 106 & 100,0 \\
\hline Sikap & Frequency & Percent $(\%)$ \\
\hline Baik & 100 & 94,3 \\
Kurang Baik & 6 & 5,7 \\
\hline Total & 106 & 100,0 \\
\hline Dukungan Keluarga & Frequency & Percent $(\%)$ \\
\hline Memberikan Dukungan & 99 & 93,4 \\
Kurang Memberikan Dukungan & 7 & 6,6 \\
\hline Total & 106 & 100,0 \\
\hline Perilaku ibu Balita & Frequency & Percent $(\%)$ \\
\hline Baik & 88 & 83,0 \\
Tidak Baik & 18 & 17,0 \\
\hline Total & 106 & 100,0
\end{tabular}

Sebagian besar responden memiliki pengetahuan yang baik yaitu sebanyak 101 responden $(95,3 \%)$, dan pada pengetahuan kurang baik yaitu sebanyak 5 responden $(4,7 \%)$. Sebagian besar responden memiliki sikap baik yaitu 100 responden $(94,3 \%)$, sedangkan pada sikap kurang baik yaitu sebanyak 6 responden $(5,7 \%)$. Sebagian besar responden memiliki dukungan keluarga baik yaitu 99 responden (93,4\%), sedangkan pada dukungan keluarga tidak baik yaitu 7 responden $(6,6 \%)$. Bahwa sebagian besar responden memiliki perilaku ibu baik yaitu 88 responden $(83,0 \%)$, sedangkan pada perilaku ibu balita yang tidak baik yaitu 18 responden $(17,0 \%)$.

Tabel 3

Pengaruh Pengetahuan Terhadap Perilaku Keaktifan Kunjungan Ibu Balita Ke Posyandu

\begin{tabular}{ccc}
\hline Variabel & $\boldsymbol{\rho}$-value & OR \\
\hline Pengetahuan & .848 & 1.044 \\
\hline
\end{tabular}

Hasil analisis bivariat penelitian ini menunjukkan bahwa tidak ada pengaruh antara pengetahuan dengan perilaku keaktifan kunjungan ibu balita ke Posyandu dengan hasil uji 
regresi logistik $\rho=0,848$ sehingga $\rho>0,05$ maka $\mathrm{H}_{0}$ pada penelitian ini di terima, artinya tidak ada pengaruh antara pengetahuan dengan perilaku keaktifan kunjungan ibu balita ke Posyandu di Posyandu Tompo Kecamatan Taopa Kabupaten Parigi Moutong.

Tabel 4

Pengaruh Sikap Terhadap Perilaku Keaktifan Kunjungan Ibu Balita Ke Posyandu

\begin{tabular}{ccc} 
Variabel & $\boldsymbol{\rho}$-value & OR \\
\hline Sikap & .001 & 2.374 \\
\hline
\end{tabular}

Berdasarkan penelitian yang dilakukan dilapangan menunjukkan bahwa terdapat pengaruh antara sikap dengan perilaku keaktifan kunjungan ibu balita ke Posyandu dengan hasil uji regresi logistic $\rho=0,001$ sehingga $\rho<0,05$ maka $\mathrm{H}_{0}$ pada penelitian ini ditolak, artinya ada pengaruh antara sikap dengan perilaku keaktifan kunjungan ibu balita ke Posyandu di Posyandu Tompo Kecamatan Taopa Kabupaten Parigi Moutong.

\section{Tabel 5}

Pengaruh Dukungan Keluarga Terhadap Perilaku Keaktifan Kunjungan Ibu Balita Ke Posyandu

\begin{tabular}{ccc}
\hline Variabel & p-value & OR \\
\hline Dukungan Keluarga & .001 & 2.930 \\
\hline
\end{tabular}

Hasil analisis bivariat menunjukkan bahwa terdapat pengaruh antara dukungan keluarga dengan perilaku keaktifan kunjungan ibu balita ke Posyandu dengan hasil uji regresi logistic $\rho=0,001$ sehingga $\rho<0,05$ maka $\mathrm{H}_{0}$ pada penelitian ini ditolak, artinya ada pengaruh antara dukungan keluarga dengan perilaku keaktifan kunjungan ibu balita ke Posyandu di Posyandu Tompo Kecamatan Taopa Kabupaten Parigi Moutong.

\section{PEMBAHASAN}

\section{Pengaruh Pengetahuan Terhadap Perilaku Keaktifan Kunjungan Ibu}

Pengetahuan adalah suatu hasil dari rasa keingintahuan seseorang. Pengetahuan sangat penting dalam membentuk perilaku seseorang. Manusia memperoleh pengetahuan melalui mata dan telinga seperti membaca dan mendengarkan. Pengukuran pengetahuan dapatdilakukan melalui wawancara atau angket untuk menanyakan mengenai isi materi yang ingin diukur dari sebuah subjek-subjek penelitian atau responden (7).

Hasil penelitian ini menunjukkan bahwa tidak ada pengaruh antara pengetahuan dengan perilaku keaktifan kunjungan ibu balita ke Posyandu di Posyandu Tompo Kecamatan Taopa Kabupaten Parigi Moutong. 
Beberapa ibu yang memiliki pengetahuan rendah namun mereka tetap aktif dalam berkunjung ke Posyandu, hal ini dikarenakan ibu merasa bahwa kesehatan anak sangat penting sehingga mendorong ibu untuk mengikuti kegiatan Posyandu. Selain itu faktor lain yaitu jarak rumah ke Posyandu yang dekat,dan pengaruh dari teman yang lain sehingga mereka aktif untuk berkunjung ke Posyandu. Ibu Balita yang memiliki pengetahuan tinggi namun tidak aktif dalam berkunjung ke Posyandu dikarenakan faktor kesibukan, umur balita, imunisasi balita dan kesehatan balita. Kesibukan ibu yang bekerja pada saat hari kegiatan Posyandu akan menyebabkan ibu tidak sempat membawa Balitanya. Ibu Balita beranggapan apabila imunisasi balitanya telah lengkap dan keadaan balita sehat maka tidak perlu lagi membawa Balita ke Posyandu.

Berdasarkan teori Notoadmodjo bahwa faktor-faktor yang mempengaruhi pengetahuan yaitu umur, semakin bertambah usia maka semakin luas wawasan yang dimiliki sehingga pengetahuan yang diperoleh semakin membaik. Begitu juga dengan pendidikan, semakin tinggi pendidikan seseorang maka akan semakin bertambah luas wawasannya sehingga lebih banyak lagi informasi yang didapatkan dan semakin mudah menerima informasi. Selain itu pengalaman pribadi juga mempengaruhi pengetahuan seseorang. Dengan pengalaman, seseorang dapat memperoleh banyak informasi dari kebenaran pengetahuan dan pengalaman pribadi (7).

Pengetahuan responden sebagian besar baik tapi tidak berkunjung ke Posyandu dikarenakan responden mengikuti suaminya pergi ketempat kerja berhari-hari dan jauh dari tempat tinggal responden sehingga tidak sempat membawa anaknya ke Posyandu. Selain itu responden sudah mengetahui tentang pengertian Posyandu, kegiatan yang dilakukan di Posyandu, manfaat Posyandu dan alur pelayanan meja di Posyandu ketika menimbang balita di Posyandu. Pada hasil penelitian masih ada responden yang memiliki pengetahuan kurang hal ini disebabkan responden kurang memahami tentang Posyandu dan kurangnya terpapar informasi karena sebagian besar responden tidak bekerja atau IRT sibuk dengan pekerjaan rumah tangga tidak sempat untuk bertukar informasi seperti ibu yang bekerja, sehingga menyebabkan pengetahuan ibu kurang.

Hasil penelitian ini sejalan dengan penelitian yang menyatakan bahwa tidak terdapat hubungan antara pengetahuan dengan perilaku ibu dalam partisipasi di Posyandu (8). Hasil penelitian ini juga sejalan dengan penelitian menyatakan bahwa tidak ada hubungan antara pengetahuan ibu Balita dengan kunjungan balita ke Posyandu (9). 
Faktor yang dapat membentuk perilaku tanpa dilandasi pengetahuan terlebih dahulu antara lain motivasi ibu, jarak tempat tinggal, serta dukungan keluarga. Selain itu jarak tempat tinggal yang dekat dengan kegiatan memudahkan ibu untuk berkunjung ke Posyandu (10).

Hasil penelitian ini tidak sesuai dengan penelitian yang dilakukan di wilayah kerja Puskesmas Banjarbaru Selatan, menunjukkan bahwa ada hubungan yang signifikan antara pengetahuan dengan keaktifan ibu membawa balita ke Posyandu (11)

Menurut pendapat peneliti bahwa ibu Balita yang mempunyai pengetahuan yang baik tentang kesehatan belum tentu memberikan perilaku yang baik pada ibu balita untuk melakukan penimbangan ke Posyandu. Setiap pengetahuan seseorang dipengaruhi beberapa faktorya itu seperti pendidikan, pekerjaan, umur dan informasi. Informasi yang dimaksud yaitu kemudahan untuk memperoleh suatu informasi sehingga mempercepat seseorang memperoleh pengetahuan baru.Pengetahuan ibu akan manfaat Posyandu dapat diperoleh dari kader Posyandu di lingkungan sekitar maupun petugas kesehatan lainnya. Selain itu dapat diperoleh dari pengalaman pribadi, sehingga dengan pengalaman-pengalaman dan informasi yang diperoleh tersebut dapat meningkatkan pengetahuan ibu akan pentingnya manfaat Posyandu yang menjadi dasar menentukan sikap dan dapat mendorong motivasi ibu balita untuk selalu membawa balitanya ke Posyandu.

\section{Pengaruh Sikap Terhadap Perilaku Keaktifan Kunjungan Ibu Balita Ke Posyandu}

Sikap merupakan predisposisi evaluasi yang banyak menentukan cara individu bertindak akan tetapi sikap dan tindakan seringkali jauh berbeda, hal ini karena tindakan nyata ditentukan tidak hanya oleh sikap akan tetapi oleh berbagai factor eksternal lainnya. Sikap tidaklah sama dengan perilaku dan perilaku tidaklah selalu mencerminkan sikap seseorang, sebab seringkali terjadi bahwa seseorang memperlihatkan tindakan yang bertentangan dengan sikapnya. Sikap seseorang dapat berubah dengan diperolehnya tambahan informasi tentang objek tersebut melalui persuasi serta tekanan dari kelompok sosialnya (12)

Sikap adalah respon tertutup seseorang terhadap stimulus atau objek tertentu, yang sudah melibatkan factor pendapat dan emosi yang bersangkutan senang dan tidak senang, setuju dan tidak setuju, baik dan tidak baik dan sebagainya (12).

Berdasarkan penelitian yang dilakukan dilapangan menunjukkan bahwa terdapat pengaruh antara sikap dengan perilaku keaktifan kunjungan ibu Balita ke Posyandu di Posyandu Tompo Kecamatan Taopa Kabupaten Parigi Moutong. 
Hasil penelitian yang peneliti dapatkan bahwa ibu balita yang memiliki sikap positif tentang Posyandu tapi tidak aktif ke Posyandu halini berhubungan dengan ibu balita yang lupakan jadwal Posyandu dan informasi jadwal ke Posyandu yang tidak jelas serta tidak adanya dukungan suami juga merupakan penyebab beberapa ibu balita tidak rutin berkunjung ke Posyandu, saat penelitian ada beberapa ibu yang dilarang oleh suami untuk berkunjung ke Posyandu dengan alas an Balitanya ketakutan ketika ditimbang dan kurangnya kesadaran karena responden lebih mementingkan ikut ketempat kerja suaminya.

Menurut penelitian yang dilakukan menunjukkan bahwa ibu Balita yang memiliki sikap tidak baik mempunyai kemungkinan lebih besar untuk berpartisipasi tidak aktif ke Posyandu dari pada ibu balita yang memiliki sikap yang baik (13). Sikap positif yang dimiliki ibu balita tentang Posyandu tapi tidak aktif ke Posyandu memiliki beberapa alasanya itu jumlah balita dalam keluarga, informasi jadwal Posyandu yang tidak jelas, tidak adanya dukungan dari suami untuk berkunjung ke Posyandu dengan alas an Balitanya ketakutan ketika ditimbang dan ada yang merasa anaknya jadi banyak jajan ketika berkunjung ke Posyandu (13). Hasil ini sejalan dengan yang dilakukan di Desa Sumber Datar yang menunjukkan bahwa ada hubungan sikap ibu Balita tentang Posyandu dengan kunjungan ibu Balita ke Posyandu. Ibu Balita yang memiliki sikap tidak baik mempunyai kemungkinan lebih besar untuk berpartisipasi tidak aktif ke Posyandu dari pada ibu balita yang memiliki sikap yang baik (14).

Penelitian ini juga sejalan dengan penelitian yang dilakukan dengan judul hubungan tingkat pendidikan, tingkat pengetahuan dan sikap ibu Balita dengan kunjungan ke Posyandu di wilayah kerja Puskesmas Belawang yang menunjukkan bahwa ada hubungan sikap ibu balita dengan kunjungan ke Posyandu (9).

Penelitian ini tidak sejalan dengan penelitian yang menunjukkan tidak terdapat hubungan antara sikap dengan perilaku ibu dalam partisipasi di Posyandu (11). Sikap seseorang dalam berperilaku dapat dipengaruhi oleh pengetahuan yang dimilikinya, dimana semakin tinggi tingkat pengetahuan seseorang akan suatu hal maka makin baik pula sikap yang dimilikinya (12).

\section{Pengaruh Dukungan Keluarga Terhadap Perilaku Keaktifan Kunjungan Ibu Balita Ke Posyandu}

Keluarga merupakan bagian terkecil dari masyarakat yang terdiri dari kepala keluarga dan anggota keluarga lainnya yang bertempat tinggal di dalam satu rumah karena adanya hubungan darah maupun ikatan pernikahan. Dukungan keluarga adalah sikap, tindakan 
penerimaan keluarga terhadap anggota keluarganya berupa dukungan informasional, dukungan penilaian, dukungan instrumental dan dukungan emosional. Jadi, dukungan keluarga adalah suatu bentuk hubungan interpersonal yang meliputi sikap, tindakan dan penerimaan terhadap anggota keluarga, sehingga anggota keluarga merasa ada yang memperhatikan (5).

Mendapatkan dukungan keluarga akan membuat ibu lebih bersedia mengunjungi Posyandu setiap bulan. Adanya dukungan keluarga seperti memberikan informasi, mau mengantar dan menemani ibu selama di Posyandu akan membuat ibu tidak merasa sendirian (1).

Ibu yang memiliki balita dengan keaktifan kunjungan ke Posyandu yang aktif sebagian besar mendapat dukungan dari keluarga, berupa dukungan moral, dukungan material dan dukungan lainnya sehingga ibu aktif dalam berkunjung ke Posyandu. Dukungan keluarga perlu diberikan kepada ibu agar turut aktif dalam berbagai kegiatan program kesehatan yang diadakan di masyarakat seperti KP-Ibu. Dukungan keluarga akan membuat ibu lebih bersedia mengunjungi posyandu setiap bulan. Adanya dukungan keluarga seperti memberikan informasi, mau mengantar dan menemani ibu selama di posyandu akan membuat ibu tidak merasa sendirian (15).

Berdasarkan penelitian yang dilakukan di lapangan menunjukkan bahwa terdapat pengaruh antara dukungan keluarga dengan perilaku keaktifan kunjungan ibu Balita ke Posyandu di Posyandu Tompo Kecamatan Taopa Kabupaten Parigi Moutong.

Berdasarkan hasil survey yang peneliti dapat di lapangan bahwa sebagian besar responden memiliki dukungan keluarga baik. Peran suami dan keluarga ibu Balita sangat penting untuk mendorong responden agar mengunjungi Posyandu. Salah satu faktor yang membuat ibu rutin ke Posyandu karena adanya dukungan keluarga seperti keluarga mengingatkan jadwal Posyandu dan suami mengantar ketempat Posyandu. Hasil penelitian ini sejalan dengan teori Friedman yang mengatakan bahwa peran didasarkan pada persepsi dan harapan peran yang menerangkan apa yang individu-individu harus lakukan dalam situasi tertentu agar dapat memenuhi harapan orang lain menyangkut peran-peran tersebut. Peranperan tersebut dibagi atas 2 yaitu yang pertama adalah peran formal atau instrumental, dimana peran yang tampak jelas bersifat eksplisit misalnya peran suami, ayah dan sebagainya. Selain itu peran emosional yaitu dukungan atau dorongan dari suami misalnya saran ibu balita mau melakukan kunjungan ke Posyandu untuk melakukan imunisasi. Kemudian peran financial seperti mengantar ibu Balita ke Posyandu. 
Hasil ini sejalan dengan penelitian yang menyatakan bahwa dukungan keluarga yang semakin baik akan meningkatkan kunjungan ibu Balita ke Posyandu. Dukungan tersebut memberikan motivasi kepada ibu dalam membawa anaknya ke Posyandu untuk mengetahui pertumbuhan dan perkembangan anaknya (16).

Penelitian ini sejalan dengan penelitian yang menunjukkan ada hubungan antara dukungan keluarga dengan perilaku ibu balita dalam menimbang anaknya ke Posyandu (14). Ibu Balita akan aktif ke Posyandu jika ada dorongan dari orang terdekat termasuk keluarga. Keluarga merupakan system dasar dimana perilaku sehat dan perawatan kesehatan diatur, dilakukan dan diamankan keluarga preventif dan bersama-sama merawat anggota keluarga.

Keluarga memiliki tanggung jawab utama untuk memulai dan mengkoordinasikan pelayanan yang diberikan oleh petugas Kesehatan (5).

Hasil dari penelitian ini juga sesuai dengan teori yang dijelaskan bahwa keberadaan anggota keluarga dan dukungan yang diberikan memiliki peranan penting dalam mencegah atau menunda seseorang yang menderita penyakit kronis untuk pergi berobat. Selain itu, dukungan yang diberikan dapat berupa dukungan emosional, dukungan penghargaan, informasional dan instrumental yang mampu mempengaruhi minat seseorang dalam berperilaku.

\section{KESIMPULAN DAN SARAN}

Kesimpulan dari penelitian ini adalah sebagai berikut yaitu ada pengaruh antara sikap $(\rho=0,001)$ dan dukungan keluarga $(\rho=0,001)$ terhadap perilaku keaktifan kunjungan ibu Balita ke Posyandu sedangkan pengetahuan $(\rho=0,848)$ tidak ada pengaruh terhadap perilaku keaktifan kunjungan ibu Balita ke Posyandu.

Disarankan bagi petugas kesehatan atau pengelola program Posyandu senantiasa mengajak ibu balita untuk membawa balitanya ke Posyandu dan selalu mengsosialisasikan pada ibu waktu kegiatan Posyandu dan memberikan penyuluhan tentang Posyandu khususnya fungsi dan tujuan Posyandu.Saran bagi penelitian selanjutnya, diharapkan untuk menambahkan beberapa variabel lain yang tidak diteliti dalam penelitian ini seperti buku KMS, dukungan petugas kesehatan dan kinerja kader.

\section{DAFTAR PUSTAKA}

1. Munawaroh S, Sakung J, Lestari A. Faktor-faktor yang berhubungan dengan keaktifan kunjungan ibu anak balita ke posyandu kelurahan buol kecamatan biau kabupaten buol. 2019;009:428-37. 
2. Kemenkes RI. Profile Kesehatan Indonesia 2019. Jakarta: Kementerian Kesehatan RI; 2018.

3. Riskesdas K. Hasil Utama Riset Kesehata Dasar (RISKESDAS). J Phys A Math Theor [Internet]. 2018;44(8):1-200. Available from: http://arxiv.org/abs/1011.1669\%0Ahttp://dx.doi.org/10.1088/1751-

8113/44/8/085201\%0Ahttp://stacks.iop.org/1751-

8121/44/i=8/a=085201 ?key=crossref.abc74c979a75846b3de48a5587bf708f

4. Dinkes Provinsi Sulteng. Profil Kesehatan Provinsi Sulawesi Tengah Tahun 2018. 2018. 1-202 p.

5. Amalia E, Syahrida S, Andriani Y. Faktor Mempengaruhi Kunjungan Ibu Membawa Balita Ke Posyandu Kelurahan Tanjung Pauh Tahun 2018. J Kesehat PERINTIS (Perintis's Heal Journal). 2019;6(1):60-7.

6. Profil Puskesmas Taopa. Kabupaten Parigi Moutong; 2019.

7. Notoatmodjo S. Metodologi Penelitian Kesehatan. Jakarta: Rineka Cipta; 2014.

8. Noeralim, Laenggeng Y. Factors Related To Visit Frequency of Infansts ' Mothers on. Faktor-Faktor yang Berhubungan dengan Keaktifan Kunjungan Balita ke Posyandu di Desa Watuawu Kec Lage Kabupaten Poso. 2016;323-33.

9. Rianto, Deanita Putri. "Analisis Faktor Niat Keaktifan Ibu dalam Melakukan Kunjungan Posyandu Balita Berdasarkan Theory of Planned Behavior." Journal of Health Science and Prevention 4.1 (2020): 42-49.

10. Nurmala. Promosi Kesehatan. Airlangga University Press; 2020.

11 Isnoviana, Meivy, and Jesica Yudit. "Hubungan Status Pekerjaan dengan Keaktifan Kunjungan Ibu dalam Posyandu di Posyandu X Surabaya." Jurnal Ilmiah Kedokteran Wijaya Kusuma 9.2 (2021): 112-122.

12. Wawan A, Dewi M. Teori dan pengukuran pengetahuan, sikap dan perilaku manusia. Yogyakarta Nuha Med. 2010;11-8.

13. Dewi, Sri Wulan Ratna, Yuyun Rahayu, and Wildaningsih Wildaningsih. "Dukungan Keluarga dan Kunjungan Balita ke Posyandu." 2-TRIK: TUNAS-TUNAS RISET KESEHATAN 10.1 (2020): 32-37.

14. Sari, Chanif Kurnia. "Faktor-Faktor yang Mempengaruhi Kunjungan Balita di Posyandu." Jurnal Keperawatan 13.1 (2021): 49-60.

15 Widiyanto, Juli, and Supryati Zebua. "Faktor Eksternal Yang Berhubungan Dengan Minat Ibu Melakukan Kunjungan Ke Posyandu." Photon: Jurnal Sain Dan Kesehatan 11.1 (2020): 68-77.

16. Setiyaningsih, Atik, and Titik Wijayanti. "Hubungan Pengetahuan Ibu dan Dukungan Keluarga dengan Keaktifan Kunjungan Posyandu Balita Mekarsari Desa Kanoman." Jurnal Komunikasi Kesehatan (Edisi 17) 9.02 (2018): 109-114. 